\title{
Liberal Ideals and Professional Aims in American Higher Education: Arguments Based on Western Philosophers' Views
}

\author{
Wei $\mathrm{Xu}^{1, *}$ \\ ${ }^{1}$ School of Education, Shanghai International Studies University, Shanghai, China \\ *Correspondence: School of Education, Shanghai International Studies University, \\ Shanghai, China. E-mail: wei_xu@shisu.edu.cn
}

Received: July 25, 2014 Accepted: August 26, 2014 Published: October 27, 2014

doi:10.5296/ije.v6i4.6139 URL: http://dx.doi.org/10.5296/ije.v6i4.6139

\begin{abstract}
Different western philosophers argued for the aims of education, especially higher education, with a focus on either its liberal ideals or professional aims, or both. Their philosophical views reflect the respective rationality of liberal education and vocational preparation in American higher education. To meet the diverse demands of labor market in such an economically and politically changeable world, it is, thus, reasonable to integrate programs in career and technical fields with those in liberal arts fields without losing the goal of general education - cultivating the mind and perfecting the intellect, ultimately reaching the development of the whole person.
\end{abstract}

Keywords: Higher education, Liberal education, Vocational preparation 


\section{Introduction}

Historically, "liberal education" has taken an eminent place in higher education of many countries. Most universities require their undergraduates, in pursuit of breadth of knowledge and understanding about the world in which they live, to complete certain liberal education in such core areas as mathematics, social studies, humanities and natural sciences.

However, as a result of industrialization in the 19th and early 20th centuries, the preparation of middle class professionals was required of higher education to face the challenges of the marketplace. With the recent changes in the economy since the 1980's, and with the emergence of informational, global, and networked society, higher education was further challenged, turning to the more pragmatic, professional, and career-training dimension. Consequently, college curricula have become excessively work-related to meet the demands of a high skill, competitive science, and business management, and have been designed to prepare the undergraduates for specific jobs.

Therefore, higher education has been pushed to confront the challenges brought about by the importance of professional training and the influence of the marketplace on liberal education. An important issue raised here is how to take account of both the value of liberal education and the prominence of vocational preparation in the new millennium and attach to each its due weight in higher education.

With regard to the purpose of higher education, there always exists the conflict between liberal education and vocational preparation, which have long been considered as two distinct tendencies in education. When education is getting more closely tied to the economy, calls for vocationalisation of education always become more strident. This article traces the philosophical bases for both literal education and vocational preparation, and explores philosophers' opinions on the relationship between the liberal ideals and professional aims in higher education. With this, a better understanding is expected of the aim of higher education in this changing world. Moreover, on the basis of an enquiry into the issue of the increasing instability of liberal education and the upgrading vocational factor in higher education, a clear idea can be formed about whether vocational preparation conflicts with liberal education, and whether a balance can be kept as to the proper proportion of liberal education and vocational preparation to meet the diverse needs of the increasing number of students in higher education today.

\section{Philosophical Arguments for Liberal Education}

A philosophical lens is an important foundation for understanding our higher education today. Christopher Dawson pointed out, "The tradition of liberal education in Western culture is practically as old as the Confusion in China and has played a similar part in forming the mind and maintaining the continuity of our civilization" (1965, p. 11). The practice of liberal education in American higher education must trace back to the arguments for education by ancient Greek philosophers, such as Socrates, Plato, and Aristotle. And, possible conflicts between liberal and vocational education can trace back to the different perspectives taken by 
these philosophers and the different understanding of educational aims by their opposites. For example, the ancient Greeks argued for the development of the whole person in education, while their opposites argued for a sense of utility in education, indicating the promise of personal and material pursuit via intellectual training.

Socrates involved people in dialogue, questioning them about the meaning of courage, justice, and piety, forcing them to think philosophically and confront their own ignorance and lack of understanding, and driving them step by step toward a moral life. For Socrates, becoming an intellectual and moral being is more important than merely succeeding in material ways. Socrates thought that the incompleteness of the educational emphasis lied in the emphasis put on ability cultivation involving speech and persuasions (esp. grammar, style, and rhetoric) because these abilities could be utilized easily for earning success in the world. Thus Socrates is surely opposed to vocational preparation in education since he is even against the practical elements contained in "liberal arts."

Then Plato, a follower of Socrates, expanded the Greek debate on civil education to the level of higher education because he thought the focus of science and philosophy in higher education would promise the final spiritual goal of the individual. On the basis of his discussions about the education of the Guardians in the Republic, and popular education in the Laws, Plato argued for the integration of appetite, the spirited element, and the gentle or philosophic element, which he considered as the three elements of human nature. Only when a person has acquired all the three elements together in a harmonious state, can he/she reach the wholeness, and be prepared to fulfill whatever responsibilities for either material pursuits or business accomplishment or state leadership. Plato suggested that men should receive such an education in excellence, focusing on integration and wholeness, when they are young because this kind of education arouses their passion for becoming perfect citizens who, being either the ruler or the ruled, should have the knowledge of how to behave on the principles of justice (1974, 643e). In The Republic, Plato described the well-nurtured youth as one

Who would see most clearly whatever was amiss in ill-made works of man or ill-grown works of nature, and with a just distaste would blame and hate the ugly even from his earliest years and would give delighted praise to beauty, receiving it into his soul and being nourished by it, so that he becomes a man of gentle heart. All this before he is of an age of reason; so that when Reason at length comes to him, then, bred as he has been, he will hold out his hands in welcome and recognize her because of the affinity he bears to her (Plato, 1974, 402a).

So what Plato advocated here is the kind of fundamental education for young men who are cultivated to own the abilities of discovering, appreciating and believing in beauty, truth and reason that are essential for humanness. Based on this essentialism, we could argue that to make schooling be valid for all, a well-grounded form to take is liberal education.

Aristotle, a pupil of Plato, argued strongly against an education solely for utility, and opposed those who considered learning as an instrument to pursue successes in ordinary activities of life because from his perspective, in addition to its instrumental functions, a learning should also be taken as an end, which is the heart of learning $(1965,982 b)$. Aristotle based the 
argument on his belief in the meaningfulness of human life and the existence of wisdom (Aristotle, 1962). In other words, things are possibly done for different reasons, whether right or wrong, and exactly those reasons matter the most in defining how meaningful our lives are. Then it is knowledge that helps people understand what must be done, and what is best in the whole of nature. Clearly, it is for the sake of understanding, but not some utility that people pursue knowledge. People need to understand those reasons that things should be done. Thus, assisting people in the pursuit of answers to why-questions is the purpose of liberal education that provides people experiences of acquiring knowledge. Moreover, for both Aristotle and Plato, the aim of education is to train people in certain ways since they are infants so that they are able to experience proper feelings, joy or grief, at the right objects or events. This is precisely the true meaning as well as the exact attempt of liberal education - helping people to discover the meaning of being human, and decide on the best approach to live that out. Thousands of years later, a similar voice can be heard from Jacques Maritain who insists "... the chief task of education is above all to shape man, or to guide the evolving dynamism through which man forms himself as a man" (1943, p.1).

In this sense, education is definitely an end in itself. This Aristotelean idea is also echoed by Cardinal John Newman (1957), who promoted education as an end in itself, divorced from all notions of utility. For Newman, a university experience should end up in cultivating the mind and perfecting the intellect, or in his own famous phrase, a "philosophical habit of mind", the possessor of which "apprehends the great outlines of knowledge, the principles on which it rests, the scale of its parts, its lights and its shades, its great points and little" (1996, V1, p.90). In addition to promoting the perfection of its possessor, such university education grants him freedom as well, the freedom of rejecting the confinement of ignorance and opinion, and the freedom of judging his surroundings accurately and reliably. Knowledge obtained from such university experience gives people freedom due to its intrinsic value for its own sake, but not any order extrinsic to itself. That is to say, such knowledge is not pursued for any external purpose or end (Newman, 1996, VII 1, p. 135). Obviously, Newman stuck to such belief that the intrinsic value of knowledge, just like health, beauty, and life, lies in itself, and any outer utilitarian purpose shall reduce its inner worth.

Therefore, the core values in traditional liberal education cover the nurture of "intellectual breadth, the development of the whole person, the cultivation of character and citizenship, and the achievement, in learning and living, of balance and harmony" (Axelrod, 1998, p.1). From Socrates, Plato, Aristotle to Newman, they all believed that a university education, other than getting people ready for jobs, should have a higher aim in providing people a consolidative experience of being intellectually and properly prepared for pursuing a nobler life. This point - liberal arts is the heart of a university education - was not only made clear by Newman (1996) in The idea of a University, but also has been justified widely ever since.

Those core values of liberal arts are still hold by many modern philosophers and educators, and also, still embraced as the central aim of liberal education for higher education in modern society. When facing the challenges of increasing economic factors in higher education before World War I, Thorstein Veblen (1918) criticized, in his The Higher Learning in America, that the ideal of university experience was invaded by business values. Such an 
intrusion was forced by the influence from wealthy businessmen on university affairs through their donations in the form of gifts and grants, which were welcomed by academic entrepreneurs in the name of managing universities and expanding their reputations. Veblen revealed that money is simply incompatible with idea, so are scholars very different from businessmen in important ways, not suiting each other at all (Veblen, 1918).

Moreover, series of programs were initiated and developed by modern philosophers, such as Robert Hutchins and Mortimer Adler, to promote liberal education. Such programs include Great Books of Foundation, the Basic Program of Liberal Education for Adults at the University of Chicago, and the Great Ideas seminars at the Center for the Study of The Great Ideas, all of which advocated the reading and an understanding of great works in the fields of philosophy, literature, history, science, and religion. And the notion of Great Books Education was championed by Allan Bloom (1987), who holds the view that the foundation of all university studies lies in a liberal education, and the core of a liberal education, the humanities closely linked to reading the ancients and concerned with essential human values.

In his article "What is Liberal Education," Mortimer Adler (n.d.) purported:

The aim of liberal education, however, is not to produce scientists. It seeks to develop free human beings who know how to use their minds and are able to think for themselves. Its primary aim is not the development of professional competence, although a liberal education is indispensable for any intellectual profession. It produces citizens who can exercise their political liberty responsibly. It develops cultivated persons who can use their leisure fruitfully. It is an education for all free men, whether they intend to be scientists or not. ... the best liberal schooling ... must include all the humanities as well as mathematics and the sciences. It must exclude all merely vocational and technical training. (paras. 6-7)

Strongly influenced by Adler, Robert Hutchins argued for the restructuring of undergraduate education in his book The Higher Learning in America, requiring students to read the greatest works of western heritage, and to practice such skills as reading, writing, thinking, speaking, and reasoning because he believed that the essentially shared intellectual experience of the western world could be passed on through generations via the college experience of learning liberal arts courses (1936, p.85).

Clearly, while arguing for the importance of liberal education, Adler and Hutchins actually pointed out the relationship between liberal education and professional preparation. And what they were against is not the inclusion of vocational instruction in a school curriculum, but the pure vocational training and narrow professional preparation. Actually, Cardinal Newman also went along with the idea that the essential task of a university is to prepare young men so that they are able "to fill any post with credit, and to master any subject with facility" (1996, p.126). Then how have other philosophers been arguing for vocational preparation? 


\section{Philosophical Arguments for Vocational Preparation}

Since the age of the Enlightenment, university curricula have put "liberal arts" in their traditional study areas. In the early days, liberal arts courses, such as those medieval trivium (grammar, logic and rhetoric) and quadrivium (arithmetic, geometry, music and astronomy), were considered compulsory for the education of professionals, especially in the fields of theology, canon law, and civil law. These subjects still held essential positions, whether as the entire focus of a college or as the basic component of a general education, in higher education up to the 1900s. However, the importance of this liberal arts tradition has been on the wane in higher education since the 1980s. According to Cataldi's overview of the career and technical education (CTE) in the United States, about $65 \%$ of 17 million undergraduates around, working towards postsecondary degrees or certificates in 2004, were seeking a degree in a CTE field, and in 2006, a CTE degree or certificate was awarded at $94 \%$ of the 6,502 postsecondary institutions (2009, pp.11-2). Clearly, baccalaureate degrees are now career-centered. Such a fact is revealed in the popularity of vocational curricula at different universities. Unavoidably, higher education is getting closely linked to the market place.

When university education aims at preparing people for vocations, its main focus is to build their abilities and skills to accomplish different tasks effectively for work, family or the society (Pring, 1995, p.187). The best way to develop such abilities and skills is supposedly to practice them under superintendence, that is, learning by doing. The contributions of such thinkers as John Locke, Jean Rousseau, Alfred North Whitehead, and John Dewey set a base for the rationality of vocational preparation.

John Locke still has a lot of influence over contemporary educational practices. Locke (1968) held the opinion that an individual should be instructed in the field of manual and mechanical trades so that he or she gets prepared for practical life from their educational experiences. For him, education is as means, not as an end for itself. Locke once analyzed how relatively important different subjects of study. For example, Locke did not think that it is reasonable for a father to want his son to become a poet and he put being excellent in music the last choice of accomplishments, but he contended that learning algebra for its utility is important even for adults because algebra helps people understand things from new perspectives (Locke, 1968, p.53).

These contentions sound so different from those of ancient philosophers, who perceived music and mathematics as two of the most valuable subjects to learn, but not for their utilitarian functions For instance, Plato argued that "Geometry ... is knowledge of what eternally exists. ... geometry must tend to draw the soul towards truth, and to give the finishing stroke to the philosophic spirit ..." (Cahn, 2009, p.96). So, according to the ancients, philosophy will be the ultimate destination of learning mathematics properly. However, for Locke, it is essential to utilize knowledge. Rousseau echoed Locke in his most renowned work Emile with experiences from his own diverse background (Rousseau, 1921). Rousseau's perception of an ideal education was revealed in the young character of Emile who received instructions of nature and the manual arts. Rousseau advocated the notion that the value of learning lies in an apprentice's experience of solving problems in a workplace instead of a 
student's rote learning in a classroom. And apprenticeship actually is an important part in vocational education, though today we also use a different term, such as internship.

Whitehead's support of vocational training in a modern university is obvious in his support for the Harvard Business School. Being not an arm-chair philosopher, Whitehead stands for the combine of theory and practice, with which, in his opinion, thought and action must result in distinctive efficiency. If school learning is detached from meaningful contexts and tends to become a matter of learning rules and saying or writing things according to the rules, whether or not the student knows the reason for the rules, Whitehead described this as the problem of "inert knowledge" - knowledge of principles without experience in understanding their implications for, and relevance to, specific situations. Whitehead argued "The solution which I am urging is to eradicate the fatal disconnection of subjects which kills the vitality of our modern curriculum. There is only one subject matter of education, and that is life and all of its manifestations" (1929, p.10). And for Whitehead, "education is the acquisition of the art of the utilization of knowledge" (1929, p.77).

Nevertheless, the above arguments for vocational preparation do not mean that philosophers, such as Whitehead and others, are the proponents of mere vocational training in education, but do mean that it is essential to integrate the active use of knowledge into liberal education. Therefore, important as skills and techniques are in light of increasing global competition and growing economic market, great care should be taken to avoid the tendency of overemphasizing the utility approach to higher education. In fact, such utility approach is well expressed in an economic model for the existing American system of higher education in the Spellings report, in which no significant role the concept of a liberal education plays (Spelling, 2006). Nevertheless, the crisis of the US financial markets ending in the current severe economic recession is gradually cooling people's fad for commercial pursuit. This reality thus helps to undermine the economic model for higher education. Opinions on the relevance and value of liberal education in higher education to a modern society are on the rise (Hohendahl, 2011, Roth, 2014). As a result, now more than ever, a mixture model for higher education is needed to confront the challenges of accelerating change in this modern world, embracing both the notion of utility and the ideal of liberal arts.

\section{Philosophical Arguments for both Liberal Education and Vocational Preparation}

And as mentioned earlier, merely vocational training is deprecated by such liberal education advocators as Adler and Hutchins. Dewey also criticized the dominance of vocational preparation in his Democracy and Education. For Dewey, a sole emphasis on vocational training equals to the training of animals or slaves, who are only expected to function as various bits of a machine in the industrial age. What Dewey insisted is not to distinguish the liberal aspects of education from the vocational ones, but to reconsider what role the vocational aspects of education play and what its meaning is (Carr and Hartnett, 1996, pp.54-66). Whitehead once pointed out clearly, "There can be no adequate technical education which is not liberal, and no liberal education which is not technical" (1929, p.74). Therefore, the compatibility of liberal education and technical education is supported strongly 
by both liberal education advocators and vocational preparation supporters.

In the industrial era, only a small number of elites could receive liberal education, while the great mass of ordinary people were only confined to narrow "vocational training" so that they became qualified workers to make the industrial machine function effectively. Dewey advocated that such an educational system had to be supplanted by a democratic educational system comprised of both liberal and vocational aspects (Carr and Hartnett, 1996, pp. 63-4). Dewey argued for a broader sense of the term "vocation," which should not be considered as a specific job, but be referred as the way people live their lives so that their own life is meaningful while they contribute their parts at the same time to the benefits of other people in the community. In Dewey's words, "A vocation means nothing but such a direction of life activities as renders them perceptibly significant to a person, because of the consequences they accomplish, and also useful to his associates" (Dewey, 2009b, p. 307).

Apparently, Dewey was against the kind of vocation with aimlessness and parasitic dependence on others (Dewey, 2009b). It is perilous to hold the dominance of one special vocation in education because that will make human beings become undeveloped. Accord to Dewey, overspecialization, increasing a person's efficiency in an activity in which he/she specializes, makes him/her inefficient in other situations (Cahn, 2009). Hence the focus of vocational education cannot be limited to the training of technical knowledge and skills required for a single specific vocation. Dewey considered it "trade education" if people are merely trained to be technically efficient in a specialized job they pursue in the future. Such a "trade education" fails people in terms of not only bettering them for that trade, but also preparing them for other different vocations. Evidently, unlike the supporters of liberal education in ancient Greek, such liberal education advocators as Dewey do not lament people's materialism because they pursue education not for its own sake but as a means towards a vocation. Obviously, positive conditions for education can be initiated with vocational aims, especially giving people a sense of purpose and direction as they pursue education, and such a sense is pivotal in sustaining their interest and stimulating their thought. Dewey insisted that:

An occupation is a continuous activity having a purpose. Education through occupations consequently combines within itself more of the factors conductive to learning than any other method. It calls instincts and habits into play; it is foe to passive receptivity; it demands that an idea of an end be steadily maintained, so that activity cannot be either routine or capricious ... (Cahn, 2009, pp.309-10).

Moreover, Dewey argued against direct vocational training at an early stage, advocating the continuous readjustments of aims and methods facilitated during vocational preparation (Dewey, 2009a). Dewey purported the existence of potential intellectual and moral interest in all occupations, and the realization of such potential must be the utmost focus in vocational education (Dewey, 2009b).

Therefore, modern higher education must provide people integrative educational experiences more adaptable to the ever changing social, political, economic and vocational demands of the world. When considering a higher education curriculum in such an economically and 
politically changeable society, educators should design an hors d'oeuvre curriculum that is pointed and broad enough to both keep the value of traditional liberal ideals and meet diverse professional aims.

Such an integrative trend has been revealed in the philosophy of liberal education defined by the Association of American Colleges and Universities (AAC\&U), recommending the empowerment of individuals with a wide range of knowledge and "strong intellectual and practical skills" in multi-disciplinary fields, the development of "a sense of social responsibility," and the exhibited abilities to apply such learning to real-life problem-solving and challenge confrontations (AAC\&U, 2014).

Educators in different disciplinary fields have also started to explore and initiate integrate approaches in their teaching activities. For example, Petkus examined the inherent relevance and value of marketing curriculum outcomes to a liberal education and called for an enhancement of the relationship in terms of "critical and reflective thinking, formation of abstract concepts and theory, analytical skills, independent and creative thinking, leadership skills, social and emotional judgment, and oral and written communication skills" (2007, p. 39). Caron (2010) and Albertine et al. (2007) shared the opinion of promoting integrative public health programs and courses within a liberal education to create a population of college students in possession of both the professional skills of living and the hope for living well while confronting the challenges of this new millennium. And in accordance with other accounting educators' recommendation of integrating liberal and accounting education for the better development of accounting students, Shapiro and Naughton (2013) inquired into an accounting education in the public interest based on the concept of common good for both the good of individuals and the good of communities so as to promote the development of holistic persons and institutions.

Moreover, when higher education reaches out to provide an integrative educational experience, attention should be paid to the flexibility of an appropriate ratio among interests in social practice, pragmatism in intellectual evolution, and ideals of cultivating the self because its ultimate goal is the education of the whole person for the whole of life. And such cultivation of the wholeness should be contextualized in the co-existence of different oppositions and tensions during the process of globalization at this new age.

\section{Conclusion: The Integration of Liberal Education and Vocational Preparation}

In this commercially competitive modern world, people surely have different wants from their investment of time and energy in higher education. It is thus quite reasonable and unavoidable to widen the conventional curriculum, including as various subjects and activities as possible, so that people's educational experiences can grant them different benefits as needed. Therefore, it is undeniable that the school curriculum in higher education should have room for both liberal education and professional preparation. To be successful in such a demanding marketplace as this, people do need to equip themselves with both theory and practice, and should be able to attend diverse activities for both their own sake and 
utilitarian pursuits. People are entitled to acquire a more general education, which provides them opportunities not only to develop different functioning skills to pursue professional success for a living, but also to cultivate their personal appreciation of the meaning of living. Via the reexamination of the place of vocational education, its role in the reorganization and innovation of higher education will surely be realized fully and properly without the expense of the merits of liberal education. If liberal ideals and professional aims are both well conveyed in higher education, students will be given a platform to obtain abilities and skills that can be transferred from a liberal education to work settings and positions of employment. Professional knowledge and training can be carried during the process of perfecting and fulfilling of the human person.

\section{References}

Adler, Mortimer. (n.d.) What is liberal education? Retrieved October 7, 2014 from http://www.ditext.com/adler/wle.html

Alan, R. (1995). John Dewey and the high tide of American liberalism. New York: W. W. Norton \& Company.

Albertine, S., Persily, N. A., \& Riegelman, R. (2007). Back to the pump handle: Public health and the future. Liberal Education, 93(4), 32-39.

Aristotle. (1965). Metaphysics. New York: Penguin.

Aristotle. (1962). Nichomachean Ethics. New York: Penguin.

Association of American Colleges and Universities (AAC\&U). (2014). What is a 21 st century liberal education? Retrieved October 7, 2014 from http://www.aacu.org/leap/what-is-a-liberal-education

Axelrod, P. (1998). Challenges to liberal education in an age of uncertainty. Historical Studies in Education, 10(1\&2), 1-19. http://www.edu.uwo.ca/hse/98axelrod.html

Bloom, A. (1987). Closing the American Mind. New York: Simon \& Schuster.

Cahn, S. M. (Ed.). (2009). Classic and Contemporary Readings in the philosophy of Education. New York: McGraw-Hill.

Caron, R. M. (2010). Call for change in liberal education. College Teaching, 58, 1-2.

Carr, W., \& Hartnett, A. (1996). Education and the Struggle for Democracy: The Politics of Educational Ideas. Buckingham: Open University Press.

Cataldi, E. F. (2009). Career and technical education in the United States: An overview of secondary, postsecondary and adult career and technical education. Retrieved October 7, 2014 from http://www.oecd.org/education/skills-beyond-school/48599540.pdf

Dawson, C. (1965). The Crisis in Western Education. Garden City: Image Books. 
Dewey, J. (2009a). The child and the curriculum. In S. M. Cahn (Ed.). Classic and Contemporary Readings in the Philosophy of Education (pp. 274-287). New York: McGraw-Hill.

Dewey, J. (2009b). Democracy and education. In S. M. Cahn (Ed.). Classic and Contemporary Readings in the Philosophy of Education (pp. 288-324). New York: McGraw-Hill.

Hohendahl, P. U. (2011). Liberal education, university reform, and the opposition to the neoliberal university. New German Critique 113, 38(2), 159-196. http://dx.doi.org/10.1215/0094033X-1221812

Hutchin, R. (1936). The Higher Learning in America. New Haven: Yale University Press.

Locke, J. (1968). Some thoughts concerning education. In J. L. Axtell (Ed.). The Educational Writings of John Locke. Cambridge: Cambridge University Press.

Maritain, J. (1943). Education at the Crossroads. New Haven: Yale University Press.

Newman, J. C. (1996). The Idea of a University. New Haven: Yale University Press.

Petkus, E. Jr. (2007). Enhancing the relevance and value of marketing curriculum outcomes to a liberal arts education. Journal of Marketing Education, 29(1), 39-51. http://dx.doi.org/10.1177/0273475306297384

Plato. (1974). The Republic. (D. Lee, Trans.). New York: Penguin Books.

Plato. (1959). The Laws. (T. J. Saunders, Trans.). New York: Penguin Books.

Pring, R (1995). Closing the Gap: Liberal Education and Vocational Preparation. London, U.K.: Hodder and Staughton.

Roth, M. S. (2014). Beyond the University: Why Liberal Education Matters. New Haven: Yale University Press.

Rousseau, J. J. (1921). Emile, or Education. (B. Foxley, Trans.). Retrieved October 7, 2014 from http://oll.libertyfund.org/titles/2256

Shapiro, B. P., \& Naughton, M. (2013). Toward an integrated vision of undergraduate liberal and accounting education in the public interest: The holistic development of persons and institutions. Accounting and the Public Interest, 13, 14-38.

Spellings, M. (Ed., 2006). A Test of Leadership: Charting the Future of U.S. Higher Education; A Report of the Commission Appointed by Secretary of Education Margaret Spellings. $\quad$ Retrieved October 7, 2014 from http://edf.stanford.edu/sites/default/files/final-report.pdf

Veblen, T. (1918). The Higher Learning in America: A Memorandum on the Conduct of University by Business Men. Retrieved October 7, 2014 from http://www.archive.org/details/higherlearningin00vebluoft 


\section{Macrothink}

International Journal of Education

ISSN 1948-5476

2014, Vol. 6, No. 4

Whitehead, A. N. (1929). The Aims of Education and Other Essays. New York: Macmillan.

\section{Copyright Disclaimer}

Copyright for this article is retained by the author(s), with first publication rights granted to the journal.

This is an open-access article distributed under the terms and conditions of the Creative Commons Attribution license (http://creativecommons.org/licenses/by/3.0/). 